\title{
Pelaksanaan supervisi akademik oleh kepala sekolah dalam meningkatkan kompetensi profesional guru
}

\author{
Sukarmen \\ SDN 17 Batu Kunit Kecamatan IV Jurai
}

\begin{abstract}
Abstrak
Tujuan penelitian ini untuk mengetahui program, pelaksanaan, tindak lanjut dan hambatan-hambatan yang dihadapi oleh guru untuk meningkatkan kompetensi profesionalnya. Penelitian ini menggunakan metode deskriptif dengan pendekatan kualitatif. Teknik pengumpulan data melalui observasi, wawancara, dan dokumentasi. Subjek penelitian adalah 14 orang guru. Data dianalisis dengan cara mereduksi, mengambil kesimpulan dan verifikasi data. Hasil penelitian menunjukkan bahwa guru-guru belum menunjukkan kinerja sebagai seorang guru yang profesional.
\end{abstract}

Keywords: supervisi akademik, kompetensi profesional guru

\section{PENDAHULUAN}

Pendidikan adalah salah satu proses pemberian bantuan bagi manusia peserta didik untuk mengembangkan daya berpikir, daya rasa, daya fungsi dan perannya dalam kehidupan. Ketercapaian tujuan pendidikan sangat bergantung pada kecakapan dan kebijaksanaan kepemimpinan kepala sekolah yang merupakan salah satu pemimpin pendidikan.Kepala sekolah adalah seorang guru yang memiliki kelebihan jika dibandingkan dengan rekan-rekan sejawatnya.Kelebihan yang dimilikinya tersebut seharusnya menjamin pencapaian tujuan dan kualitas pendidikan di persekolahan. Menurut Suryosubroto (2010:86) "Kepala sekolah wajib mendayagunakan seluruh personel sekolah secara efektif dan efisien agar tujuan penyelenggaraan pendidikan di sekolah tersebut tercapai dengan optimal." pendayagunaan ini ditempuh dengan jalan memberikan tugas-tugas jabatan sesuai dengan kemampuan dan kewenangan masing-masing individu.

Mutu pendidikan sangat tergantung pada komponen-komponen yang terdapat dalam pendidikan, diantara komponen yang sangat mempengaruhi berhasil tidaknya pendidikan adalah tergantung dari kualitas guru dengan kata lain guru harus profesional. Guru profesional adalah orang yang memiliki kemampuan dan keahlian khusus dalam bidang keguruan sehingga mampu melakukan tugas dan fungsinya sebagai guru dengan kemampuan maksimal. Guru merupakan salah satu faktor penting dalam meningkatkan mutu pendidikan, karena gurulah yang sanggup untuk menggerakkan komponen lainnya, seperti alat-alat pelajaran/alat peraga, laboratorium dan sebagainya dalam proses belajar-mengajar. Kompenen tersebut dapat bermakna apabila dibawakan atau disajikan oleh guru yang berkualitas. Hal ini sesuai dengan pendapat Idris (2007:12) bahwa "semakin baik kualitas profesional guru akan semakin besar pula pengaruhnya terhadap peningkatan kualitas belajar mengajar." 
Sesuai dengan PP Nomor 19/2005 Pasal 28 ayat (1), pendidik harus memiliki kualifikasi akademik dan kompetensi sebagai agen pembelajaran, sehat jasmani dan rohani, serta memiliki kemampuan untuk mewujudkan tujuan pendidikan nasional. Ayat (2) kualifikasi akademik sebagaimana dimaksud pada ayat (1) adalah tingkat pendidikan minimal yang harus dipenuhi oleh seorang pendidik yang dibuktikan dengan ijazah dan/atau sertifikat keahlian yang relevan sesuai ketentuan perundang-undangan yang berlaku. Pada ayat (3), kompetensi sebagai agen pembelajaran pada jenjang pendidikan dasar dan menengah serta pendidikan anak usia dini meliputi: a) kompetensi pedagogik; b) kompetensi kepribadian; c) kompetensi profesional; dan d) kompetensi sosial. Ayat (4) seseorang yang tidak memiliki ijazah dan/atau sertifikat keahlian sebagaimana dimaksud pada ayat (2) tetapi memiliki keahlian khusus yang diakui dan diperlukan dapat diangkat menjadi pendidik setelah melewati uji kelayakan dan kesetaraan.

Salah satu upaya untuk meningkatkan profesional guru adalah melalui supervisi. Supervisi pendidikan merupakan bantuan untuk meningkatkan profesional guru melalui pembahasan secara perorangan atau berkelompok tentang kajian masalah pendidikan dan pengembangan untuk menemukan solusi atas berbagai alternatif pengembangan untuk meningkatkan profesional guru.

Hasil pengamatan dan wawancara penulis pada SD Negeri 17 Batu Kunit Kecamatan IV Jurai Kabupaten Pesisir Selatan bahwa guru mengeluhkan terhadap jarangnya supervisi yang dilaksanakan oleh kepala sekolah yang mengakibatkan guru jarang dibekali dengan kurikulum yang berlaku, kepala sekolah hanya memeriksa Rencana Pelaksanaan Pembelajaran (RPP) saja, kurang ditegakkan disiplin baik untuk guru maupunsiswa, dan kurangnya melakukan kegiatankegiatan untuk meningkatkan prestasi belajar siswa.

Menurut Danim (2011:152) bahwa "secara etimologi istilah supervisi berasal dari bahasa Inggris "supervision" yang berarti pengawasan. Pelaku atau pengawasannya disebut supervisor dan orang yang disupervisi disebut subjek supervisi."Supervisi adalah segala bantuan dari para pimpinan sekolah, yang tertuju kepada perkembangan kepemimpinan guru-guru personel sekolah lainnya di dalam mencapai tujuan-tujuan pendidikan. Menurut Suryosubroto (2010:175), "Supervisi adalah pembinaan yang diberikan kepada seluruh staf sekolah agar mereka dapat meningkatkan kemampuan untuk mengembangkan situasi belajar mengajar yang lebih baik." Supervisi merupakan bagian yang tidak terpisahkan dari seluruh proses administrasi pendidikan yang ditujukan terutama untuk mengembangkan efektivitas kinerja personalia sekolah yang berhubungan dengan tugas-tugas utama pendidikan. Hal ini sesuai dengan pendapat Mulyasa (2013:239) bahwa supervisi adalah: Segala usaha pejabat sekolah dalam memimpin guru-guru dan tenaga kependidikan lainnya, untuk memperbaiki pengajaran, termasuk menstimulasi, menyeleksi pertumbuhan dan perkembangan jabatan guruguru, menyeleksi, dan merevisi tujuan-tujuan pendidikan, bahan pengajaran dan metode-metode menagajar serta evaluasi pengajaran.

Berdasarkan beberapa pendapat ahli di atas, maka supervisi dapat dimaknai sebagai suatu kegiatan layanan dan pembinaan yang direncanakan oleh pengawas sekolah yang dilakukan secara sistematis untuk membantu para guru dan pegawai baik secara individu atau kelompok dalam usaha memperbaiki pembelajaran atau melakukan tugasnya secara efektif.

Supervisi berfungsi sebagai alat untuk memperoleh gambaran yang sebenarnya tentang situasi pendidikan sehingga dapat digunakan sebagai sarana untuk menilai situasi. Hal ini sesuai dengan pendapat Briggs (Imron, 2011:12) bahwa: Supervisi juga berfungsi untuk mengkoordinasi, menstimulasi, dan mengarahkan pertumbuhan guru-guru; mengkoordinasikan semua usaha sekolah, memperlengkapi kepemimpinan sekolah, memperluas pengalaman guru-guru, menstimulasi usaha-usaha yang kreatif, memberi fasilitas dan penilaiann yang terusmenerus, menganalisis situasi belajarmengajar, memberikan pengetahuan dan keterampilan guru serta staf, mengintegrasikan tujuan pendidikan dan membantu meningkatkan kemampuan guru.

Tujuan supervisi melekat adalah untuk mengetahui apakah pimpinan unit kerja dapat menjalankan fungsi pengawasan dan pengendalian yang melekat padanya dengan baik sehingga apabila ada penyelewengan, pemborosan, korupsi, pimpinan unit kerja dapat mengambil tindakan koreksi sedini mungkin.Sedangakan pengawasan fungsional adalah kegiatan-kegiatan pengawasan yang dilakukan oleh orang-orang yang fungsi jabatannya sebagai pengawas. Menurut Suryosubroto (2010:175) bahwa "Tujuan supervisi adalah untuk mengembangkan situasi belajar mengajar yang lebih baik melalui pembinaan dan peningkatan profesi mengajar." Tujuan supervisi adalah membantu dan memberikan kemudahan kepada para guru untuk belajar bagaimana meningkatkan kemampuan mereka guna mewujudkan tujuan belajar peserta didik.

Sasaran supervisi akademik tidak hanya guru dan siswa tetapi juga kepala sekolah dan pihak lain yang terkait di sekolah, sebab betapa penting peran kepala sekolah dalam kesuksesan proses pembelajaran. Dengan 
demikian dapat diambil kesimpulan bahwa tujuan supervisi adalah untuk meningkatkan kualitas proses pembelajaran agar menjadi lebih baik. Untuk mencapai tujuan tersebut maka dapat dilakukan dengan membina para guru melaluipemberian layanan dan bantuan dalam meningkatkan kompetensi profesionalnya sehingga proses pembelajaran yang dilakukan menjadi lebih baik dan pada akhirnya akan meningkatkan kualitas hasil belajar siswa.

Pendekatan yang digunakan dalam menerapkan supervisi modern didasarkan pada prinsip-prinsip psikologis.Suatu pendekatan atau teknik pemberian supervisi sangat bergantung kepada prototipe guru.Pendekatan yang dilakukan adalah pendekatan langsung, pendekatan tidak langsung dan pendekatan kolaboratif. Pendekatan direktif adalah cara pendekatan terhadap masalah yang bersifat langsung. Supervisor memberikan arahan langsung.Sudah tentu pengaruh perilaku supervisor lebih dominan.Pendekatan direktif ini berdasarkan pemahaman terhadap psikologi behaviorisme. Pendekatan tidak langsung (nondirektif) adalah cara pendekatan terhadap permasalahan yang sifatnya tidak langsung. Perilaku supervisor tidak secara langsung menunjukkan permasalahan, tapi terlebih dulu mendengarkan secara aktif apa yang dikemukakan guru-guru. Pemimpin memberi kesempatan sebanyak mungkin kepada guru untuk mengemukakan permasalahan yang mereka alami.Pendekatan non-direktif berdasarkan pemahaman terhadap psikologi humanistik.

Pendekatan kolaboratif adalah cara pendekatan yang memadukan cara pendekatan direktif dan non-direktif menjadi cara pendekatan baru. Pada pendekatan ini baik supervisor maupun guru bersama-sama sepakat untuk menetapkan struktur, proses dan kriteria dalam melaksanakan proses percakapan terhadap masalah yang dihadapi guru. Pendekatan ini berdasarkan pada psikologi kognitif.

Seorang kepala sekolah pada hakekatnya adalah pemimpin yang menggerakkan, mempengaruhi, memberi motivasi, serta mengarahkan orang di dalam organisasi atau lembaga pendidikan untuk mencapai tujuan yang telah ditentukan sebelumnya. Wahjosumidjo (2010:83) mengartikan bahwa "Kepala sekolah adalah seorang tenaga fungsional guru yang diberi tugas untuk memimpin suatu sekolah di mana diselenggarakan proses belajar mengajar, atau tempat di mana terjadi interaksi antara guru yang memberi pelajaran dan murid yang menerima pelajaran." Peran kepala sekolah dalam melaksanakan upaya perbaikan kualitas pendidikan adalah dengan memberikan bimbingan kepada guru dalam memperbaiki mutu proses belajar mengajar. Ukuran keberhasilan kepala sekolah dalam menjalankan peran dan tugasnya adalah dengan mengukur kemampuan dia dalam menciptakan iklim pembelajaran, dengan mempengaruhi, mengajak, dan mendorong guru, siswa, dan staf lainnya untuk menjalankan tugasnya masing-masing dengan sebaik-baiknya. Menurut Murniati (2008:146) peran kepala sekolah adalah sebagai “(1) pendidik (educator), (2) supervisor, (3) pemimpin (leader), (4) manajer, (5) administrator, (6) inovator, dan (7) motivator." Peranan kepala sekolah yang berkaitan dengan hubungan personal, mencakup kepala sekolah sebagai simbol organisasi, pemimpin dan penghubung, peranan yang berkaitan dengan informasi, mencakup kepala sekolah sebagai pemonitor yang menyebarkan informasi ke semua lingkungan organisasi, dan peranan yang berkaitan dengan pengambilan keputusan, yang mencakup kepala sekolah sebagai entrepreneur, penyedia segala sumber dan negosiator.

Berdasarkan permasalahan di atas, maka penulis tertarik untuk mengadakan penelitian yang berjudul "Pelaksanaan supervisi akademik oleh kepala sekolah dalam meningkatkan kompetensi profesional guru pada SD Negeri 17 Batu Kunit Kecamatan IV Jurai Kabupaten Pesisir Selatan ”.

\section{METODE}

Jenis penelitian ini adalah Penelitian Tindakan Sekolah (PTS). PTS merupakan suatu prosedur penelitian yang diadaptasi dari Penelitian Tindakan Kelas (PTK).Penelitian tindakan sekolah (PTS) sebenarnya mengadop prinsip prinsip yang terdapat pada penelitian tindakan atau action research. Yaitu suatu riset yang tidak saja bermaksud mengidentifikasi sejumlah masalah pada berbagai macam kegiatan, melainkan sekaligus merumuskan alternatif pemecahan, menerapkan alternatif pemecahan yang sudah dirumuskan sebagai suatu tindakan, melakukan evaluasi terhadap tindakan dan memberikan umpan balik guna merumuskan tindakan berikutnya. Kegiatan merumuskan alternatif tindakan, melakukan tindakan, evaluasi tindakan dan umpan balik dilakukan secara berulang dalam beberapa siklus

Sesuai dengan bidang kerja kepala sekolah, seorang kepala sekolah bertanggung-jawab terhadap kualitas proses dan hasil pembelajaran yang dilakukan oleh guru yang di sekolah yang dipimpinnya. Kualitas pembelajaran guru niscaya akan dapat ditingkatkan, ketika guru tersebut berkompeten dalam menjabarkan kurikulum (dalam hal ini adalah KTSP atau kurikulum-13) ke dalam perangkat-perangkat kurikulum: silabus, RPP, KKM, rencana evaluasi), melaksanakan implementasi pembelajaran, dan melaksanakan pengelolaan kelas 
Dalam penelitian ini, peneliti menggunakan pendekatan penelitian kualitatif. Penelitian kualitatif adalah penelitian tentang riset yang bersifat deskriptif dan cenderung menggunakan analisis dengan pendekatan induktif. Penelitian ini dilakukan pada SD Negeri 17 Batu Kunit Kecamatan IV Jurai Kabupaten Pesisir Selatan . Berdasarkan permasalahan yang akan dikaji dalam penelitian ini, maka yang akan menjadi subjek dalam penelitian ini adalah guru dan tenaga kependidikan.

Teknik pengumpulan data yang digunakan dalam penelitian ini yaitu melalui observasi (pengamatan), wawancara, dan dokumentasi.Satori dan Aan (2010:146) menyatakan bahwa "Dalam penelitian kualitatif, pengumpulan data dilakukan pada kondisi alamiah, sumber data primer, dan teknik pengumpulan data lebih banyak pada observasi berperan serta, wawancara mendalam dan dokumentasi”.Teknik analisis data yang digunakan dalam penelitian ini adalah teknik analisis kualitatif.Data yang peroleh melalui observasi, wawancara dan studi dokumentasi di lapangan dianalisis dan diinterpretasikan ke dalam bahasa yang lebih mudah dimengerti.

Subjek dalam penelitian ini adalah guru-guru dan tenaga kependidikan pada SD Negeri 17 Batu Kunit Kecamatan IV Jurai Kabupaten Pesisir Selatan yang berjumlah 14 orang.Rentang waktu pelaksanaan penelitian tindakan sekolah ini adalah bulan Agustus sampai Desember 2017 atau semester I tahun pelajaran 2017/2018.

Dari hasil penilitian oleh kepala sekolah ini diharapkan dapat meningkatkan profesiolisme guru-guru dan tenaga kependidikan yang ada di SD Negeri 17 Batu Kunit Kecamatan IV Jurai Kabupaten Pesisir Selatan, yang tentu saja akan beredampak terhadap hasil dan proses pembelajaran.

\section{HASIL PEMBAHASAN}

Program Supervisi Akademik yang disusun untuk Meningkatkan Kompetensi Profesional Guru Hasil penelitian menunjukkan bahwa program supervisi akademik pada SD Negeri 17 Batu Kunit Kecamatan IV Jurai Kabupaten Pesisir Selatan disusun berdasarkan petunjuk yang diberikan oleh Dinas Pendidikan. Program disusun pada setiap awal tahun pelajaran berdasarkan hasil tindak lanjut kepala sekolah tentang pelaksanaan supervisi pada tahun sebelumnya.Penyusunan program supervisi akademik tidak sepenuhnya melibatkan guru dan direncanakan sebanyak empat kali dalam setahun atau dua kali dalam satu semester. Pada intinya perencanaan dibuat sebagai upaya untuk merumuskan apa yang sesungguhnya ingin dicapai oleh sebuah organisasi atau perusahaan serta bagaimana sesuatu yang ingin dicapai tersebut dapat diwujudkan melalui serangkaian rumusan rencana kegiatan tertentu. Siswanto (2012:3) mengemukakan bahwa "perencanaan adalah suatu proses dan rangkaian kegiatan untuk menetapkan tujuan terlebih dahulu pada suatu jangka waktu/periode tertentu serta tahapan/langkah-langkah yang harus ditempuh untuk mencapai tujuan tersebut." Penyusunan program supervisi memerlukan berbagai data dan informasi, terutama yan berkaitan dengan guru dan proses belajar mengajar yang dilaksanakan. Dalam hal ini diperlukan keterbukaan dan kesediaan guru guru untuk memberikan data dan informasi mengenai permasalahan dan kesulitan yang mereka temui dalam melaksanakan tugasnya sebagai guru. Menurut Murniati (2008:138) bahwa "bidang-bidang tugas yang harus diketahui, dikuasai dan dilakukan kepala sekolah meliputi kawasan melakukan perencanaan, pengorganisasian, pengkoordinasasian, pelaksanaan, pengawasan, evaluasi dan tindak lanjut atau umpan balik."

Pelaksanaan Supervisi Akademik untuk Meningkatkan Kompetensi Profesional Guru Berdasarkan hasil penelitian bahwa pelaksanaan supervisi akademik pada SD Negeri 17 Batu Kunit Kecamatan IV Jurai Kabupaten Pesisir Selatan diawali dengan kegiatan sosialisasi kepada guru dan melakukan pertemuan pra observasi. Kegiatan supervisi dilakukan dengan memberikan bimbingan danarahan tentang penyusunan perangkat pembelajaran, pelaksanaan pembelajaran dan evaluasi pembelajaran melalui kegiaran rapat, diskusi, pertemuan individu dan observasi kelas. Kepala sekolah mencatat seluruh kegiatan guru dalam pembelajaran pada lembar instrumen pelaksanaan observasi kelas sebagai masukan dan pertimbangan untuk pembinaan dalam meningkatkan profesional guru. Supervisi akademik merupakan serangkaian kegiatan membantu guru mengembangkan kemampuannya mengelola proses pembelajaran, maka menilai unjuk kerja guru dalam mengelola proses pembelajaran merupakan salah satu kegiatan yang tidak bisa dihindarkan prosesnya. Menurut Suhardan (2010:57) bahwa "sebagai seorang supervisor yang harus mengawasi semua pekerjaan berkaitan dengan pembelajaran yaitu mengembangkan kurikulum ke dalan pembelajaran, meningkatkan kemampuan guru dalam menangani tugas mengajarnya supaya lebih efektif, serta meningkatkan kemampuan profesional stafnya." Melalui supervisi akademik diharapkan kualitas akademik yang dilakukan oleh guru semakin meningkat. Kegiatan supervisi akademik yang dilakukan kepala sekolah akan berpengaruh secara psikologis terhadap peningkatan mutu mengajar guru apabila guru menerima supervisi tersebut sebagai masukan dan motivasi untuk 
meningkatkan mutu mengajarnya sehingga akan bekerja dengan sukarela yang akhirnya dapat membuat produktivitas kerja guru menjadi meningkat.

Tetapi jika guru tidak menerima supervisi akademik sebagai suatu hal yang dapat mengakibatkan peningkatan mutu mengajar dan motivasi atau dijadikan beban maka akan bekerja karena terpaksa dan kurang bergairah yang ditunjukkan oleh sikap-sikap yang negatif sehingga mengakibatkan pruduktivitas kerja guru menjadi menurun. Selain supervisi akademik yang dilakukan oleh kepala sekolah, hal lain yang dapat mempengaruhi mutu mengajar guru adalah budaya sekolah.

Tindak Lanjut Supervisi Akademik untuk Meningkatkan Kompetensi Profesional Guru Hasil penelitian menunjukkan bahwa tindak lanjut supervisi akademik yang dilakukan oleh kepala sekolah pada SD Negeri 17 Batu Kunit Kecamatan IV Jurai Kabupaten Pesisir Selatan melalui diskusi antara kepala sekolah dengan guru sebagai pertemuan balikan yang membicarakan tentang hasil catatan kepala sekolah ketika melaksanakan observasi kelas. Hasil tindak lanjut diakhiri dengan langkahlangkah kongkrit secara kontekstual sebagai jalan keluar dari masalah-masalah yang dihadapi guru dalam proses pembelajaran dan sebagai upaya perbaikan pada masa yang akan datang untuk perbaikan dan peningkatan kualitas pembelajaran.

Langkah tindak lanjut dilakukan melaui proses dialogis antara supervisor dengan yang disupervisi untuk mendiskusikan langkah perbaikan atas kekurangan-kekurangan dan kelemahan yang dialami guru dalam proses pembelajaran. Pendekatan yang dilakukandalam diskusi tersebut harus bersifat kemitraan dan kekeluargaan, bukan bersifat intruksi dari atasan kepada bawahan, sehingga terjadi proses yang terbuka, manusiawi, dan saling menghormati untuk bersama-sama mencari solusi terbaik dalam upaya peningkatan mutu pembelajaran yang pada gilirannya akan meningkatkan mutu prestasi belajar siswa. Diskusi dalam proses tindak lanjut supervisi merupakan langkah awal dari keseluruhan proses tindak lanjut itu sendiri karena masih ada bentuk kongkrit langkah tindak lainnya yang harus dilakukan berikutnya. Mulyasa (2006:113) mengemukakan bahwa "diskusi kelompok merupakan suatu kegiatan yang dilakukan bersama guru-guru dan bisa juga melibatkan tenaga administrasi, untuk memecahkan berbagai masalah di sekolah, dalam mencapai suatu keputusan."

Hambatan-Hambatan yang Dihadapi dalam Pelaksanaan Supervisi Akademik untuk Meningkatkan Kompetensi Profesional Guru Hambatan-hambatan yang dihadapi oleh kepala sekolah dalam pelaksanaan supervisi akademik untuk meningkatkan kompetensi profesional guru pada SD Negeri 17 Batu Kunit Kecamatan IV Jurai Kabupaten Pesisir Selatan adalah kepala sekolah sering ada rapat mendadak sehingga jadwal supervisi bergeser, guru masih menggunakan metode mengajar yang berpusat pada guru, guru merasa kaku ketika disupervisi dan guru kurang aktif dalam mencari informasi baru tentang pembelajaran.

Kepala sekolah sebagai supervisor harus memerhatikan prinsip-prinsip hubungan konsultatif, kolegial, bukan hirarkhis, dilaksanakan secara demokratis, berpusat pada guru, dilakukan berdasarkan kebutuhan tenaga guru, dan merupakan bantuan profesional.Tugas kepala sekolah sebagai supervisor yaitu memberi masukan kepada tenaga kependidikan yang masih dirasa perlu dibenahi, dibina dan ditingkatkan kemampuan dan keterampilannya.Tindakan ini untuk mencegah agar para tenaga kependidikan tidak melakukan penyimpangan dan lebih berhatihati melaksanakan pekerjaannya.Kepala sekolah perlu melaksanakan pertemuan pra observasi, pelaksanaan observasi dan pertemuan balikan untuk membuat suatu kesepakatan tentang pelaksanaan supervisi kepada guru. Pertemuan pra observasi membantu guru merefleksikan apa yang akan mereka lakukan atau dapatkan sebagai usulan ide-ide untuk pengajaran yang akan dilakukan. Tujuan pertemuan ini adalah untuk menolong guru agar fokus pada materi yang akan diobservasi, menyelidiki apakah ada siswa dalam kelas yang memiliki perilaku yang harus diperhatikan secara khusus, membahas strategi dan teknik apa yang akan dipergunakan saat mengajar, menetapkan isi pelajaran, apa awal dan akhirnya, mendiskusikan harapan-harapan guru dan apa kekhawatiran guru tentang pelajaran serta menjelaskan apa peran kepala sekolah dalam observasi. 
Dari hasil pelaksanaan supervise yang telah dilakukan, terbukti bahwa meningkatkan kopentensi professional guru seperti data dibawah ini :

\begin{tabular}{|c|c|c|c|c|c|c|c|c|c|c|}
\hline \multirow[t]{2}{*}{ NO } & \multirow[t]{2}{*}{ Indikator Kompetensi } & \multicolumn{3}{|c|}{ PRA OBSERVASI } & \multicolumn{3}{|c|}{ SIKLUS I } & \multicolumn{3}{|c|}{ SIKLUS II } \\
\hline & & B & $\mathrm{C}$ & $\mathrm{K}$ & $\mathrm{B}$ & $\mathrm{C}$ & $\mathrm{K}$ & B & $\mathrm{C}$ & $\mathrm{K}$ \\
\hline \multirow[t]{2}{*}{1} & \multirow{2}{*}{$\begin{array}{l}\text { Memahami materi ajar yang ada } \\
\text { dalam kurikulum sekolah }\end{array}$} & 3 & 4 & 5 & 4 & 5 & 3 & 8 & 4 & $\mathbf{0}$ \\
\hline & & $25 \%$ & $33 \%$ & $42 \%$ & $33 \%$ & $42 \%$ & $25 \%$ & $67 \%$ & $33 \%$ & $0 \%$ \\
\hline \multirow[t]{2}{*}{2} & \multirow{2}{*}{$\begin{array}{l}\text { Memahami struktur, konsep, dan } \\
\text { metode keilmuan yang koheren } \\
\text { dengan materi ajar }\end{array}$} & 2 & 3 & 8 & 4 & 4 & 4 & 7 & 5 & $\mathbf{0}$ \\
\hline & & $17 \%$ & $25 \%$ & $67 \%$ & $33 \%$ & $33 \%$ & $33 \%$ & $58 \%$ & $42 \%$ & $0 \%$ \\
\hline \multirow[t]{2}{*}{3} & \multirow{2}{*}{$\begin{array}{l}\text { Memahami hubungan konsep antar } \\
\text { mata pelajaran terkait }\end{array}$} & 3 & 3 & 6 & 4 & 5 & 3 & 6 & 5 & 1 \\
\hline & & $25 \%$ & $25 \%$ & $50 \%$ & $33 \%$ & $42 \%$ & $25 \%$ & $50 \%$ & $42 \%$ & $8 \%$ \\
\hline \multirow[t]{2}{*}{4} & \multirow{2}{*}{$\begin{array}{l}\text { Menerapkan konsep-konsep } \\
\text { keilmuan dalam kehidupan sehari- } \\
\text { hari. }\end{array}$} & 3 & 4 & 5 & 4 & 6 & 3 & 8 & 3 & $\mathbf{1}$ \\
\hline & & $25 \%$ & $33 \%$ & $42 \%$ & $33 \%$ & $50 \%$ & $25 \%$ & $67 \%$ & $25 \%$ & $8 \%$ \\
\hline
\end{tabular}

Berdasarkan hasil observasi dan supervise sekaligus penilaian oleh Kepala Sekolah, terlihat peningkatan kemampuan guru menerapkan Komptensi Profesionalnya sebagai guru.Sebagai bahan tefleksi bagi Kepala Sekolah, bahwa supervise tidak hanya satu kompetensi yang dinilai, tetapi juga dilihat kompetensi lainnya demi peningkatan prestasi kerja guru-gurunya. Untuk itu perlu persiapan yang lebih untuk program supervise berikutnya, agar dapat melihat dan menilai guru leibh actual dan valid.

\section{KESIMPULAN}

Program supervisi akademik pada SD Negeri 17 Batu Kunit Kecamatan IV Jurai Kabupaten Pesisir Selatan disusun berdasarkan petunjuk yang diberikan oleh Dinas Pendidikan.Program disusun pada setiap awal tahun pelajaran berdasarkan hasil tindak lanjut kepala sekolah tentang pelaksanaan supervisi pada tahun sebelumnya.Penyusunan program supervisi akademik tidak sepenuhnya melibatkan guru dan direncanakan sebanyak empat kali dalam setahun atau dua kali dalam satu semester. Pelaksanaan supervisi akademik pada SD Negeri 17 Batu Kunit Kecamatan IV Jurai Kabupaten Pesisir Selatan diawali dengan kegiatan sosialisasi kepada guru dan melakukan pertemuan pra observasi. Kegiatan supervisi dilakukan dengan memberikan bimbingan dan arahan tentang penyusunan perangkat pembelajaran, pelaksanaan pembelajaran dan evaluasi pembelajaran melalui kegiaran rapat, diskusi, pertemuan individu dan observasi kelas. Kepala sekolah mencatat seluruh kegiatan guru dalam pembelajaran pada lembar instrumen pelaksanaan observasi kelas sebagai masukan dan pertimbangan untuk pembinaan dalam meningkatkan profesional guru. Tindak lanjut supervisi akademik yang dilakukan oleh kepala sekolah pada SD Negeri 17 Batu Kunit Kecamatan IV Jurai Kabupaten Pesisir Selatan melalui diskusi antara kepala sekolah dengan guru sebagai pertemuan balikan yang membicarakan tentang hasil catatan kepala sekolah ketika melaksanakan observasi kelas. Hasil tindak lanjut diakhiri dengan langkahlangkah kongkrit secara kontekstual sebagai jalan keluar dari masalah-masalah yang dihadapi guru dalam proses pembelajaran dan sebagai upaya perbaikan pada masa yang akan datang untuk perbaikan dan peningkatan kualitas pembelajaran. 4. Hambatan-hambatan yang dihadapi oleh kepala sekolah dalam pelaksanaan supervisi akademik untuk meningkatkan kompetensi profesional guru pada SD Negeri 17 Batu Kunit Kecamatan IV Jurai Kabupaten Pesisir Selatan adalah kepala sekolah sering ada rapat mendadak sehingga jadwal supervisi bergeser, guru masih menggunakan metode mengajar yang berpusat pada guru, guru merasa kaku ketika disupervisi dan guru kurang aktif dalam mencari informasi baru tentang pembelajaran. 


\section{DAFTAR RUJUKAN}

Danim, S. dan Khairi., 2011. Profesi Kependidikan. Bandung: Alfabeta.

Idris, J., 2007. Analisis Kritis Mutu Pendidikan. Banda Aceh: Taufiqiyah Sa'adah. Imron, A., 2011. Supervisi Pembelajaran Tingkat Satuan Pendidikan. Jakarta: Bumi Aksara.

Mulyasa, E., 2006. Menjadi Kepala Sekolah Profesional. Bandung: Remaja Rosdakarya.

Murniati, AR., 2008. Manajemen Stratejik (Peran Kepala Sekolah dalam Pemberdayaan). Bandung: Citapustaka Media Perintis.

Satori, D. dan Aan Komariah., 2010. Metodologi Penelitian Kualitatif. Bandung: Alfabeta.

Suryosubroto, 2010. Manajemen Pendidikan di Sekolah. Jakarta: Rineka Cipta. Wahjosumidjo, 2010. Kepemimpinan Kepala Sekolah (Tinjauan Teoretik dan Permasalahannya. Jakarta: Raja Grafindo Persada. 